\title{
Research on the Development of Modern Wood Structure Building in Cold Area
}

\author{
Jun ZHANG \\ Civil Engineering Institute \\ Northeast Forestry University \\ Harbin, China
}

\author{
Baoxin YANG \\ Civil Engineering Institute \\ Northeast Forestry University \\ Harbin, China \\ e-mail: aaybxybx@126.com
}

\begin{abstract}
Based the present situation on the development of modern wood structure building at home and abroad, the problems including the technology lag, the single building form and the single application type of the modern wooden structure building are pointed out from the view of adaptation to climate, energy saving and construction period, etc. in the cold area. In addition, the imperfection during developing in the wood structure building in our country is analyzed. Some suggestions on promoting the development of wood structure in cold area are gave in order to wood structure building in cold areas have a better development in the urbanization process.
\end{abstract}

Keywords-wood structure; architecture; development; urbanization

\section{INTRODUCTION}

At present, our country application of timber construction is not wide, the year of 2015 is the wooden structure industry for twenty-third years, and source of timber mainly imports (more than $70 \%$ ). And more than $80 \%$ of domestic wood construction companies remain in the imitation stage in the technology and structure, which is largely due to their own lack of technology and research and development investment insufficient. In September 2013, our country revised the "design of timber structures" GB5005 response to this phenomenon, which provides technical support for the new wooden structure designed. With the deepening of the real estate industry transition and our country promote the green building, which makes domestic wood construction industry to accelerate development. Through improved modern technology, wood construction has become a kind of new energy-saving green buildings, which greatly accelerated productivity of wooden architecture. Wooden architecture has many advantages [1], such as structural safety, energysaving insulation, environmentally friendly, comfortable and livable. Wooden architecture of modern technology is also suitable for industrial production. It is a form of building livable, which makes the new wooden building vigorously developed.

\section{THE CURRENT SituATION OF THE DEVELOPMENT OF BUILDING WOOD IN COLD AREA}

With the rapid development of modern industrialization in our country (More than $50 \%$ of the nation's energy was used in the construction industry), in the construction sector, reinforced concrete and steel has been occupying a dominant position, so the promotion of wood construction in the process of urbanization is not easy. In addition, the high cost of land and people's traditional concept of building preservation makes the development of wood construction may only exist in the outskirts of the city or rural areas [2]. However, wooden architecture plays a very important role in the process of urbanization Northern Europe or North America and other regions. In Japan, Korea, North America's cold climate region, In Japan, South Korea, North America and other areas of cold climate, modern wood frame construction has been rapid development, and the formation of a new architectural model, which combines modern architecture construction technology, design and energysaving ideas. Such as $40 \%$ of Japanese new buildings and over $80 \%$ of renovation buildings using wood frame construction system; more than $95 \%$ of Canada's underlying buildings are wood frame. Based situation on lacked wood at home and abroad we should revalue the appearing problems in urbanization.

\section{THE DEVELOPMENT AdVANTAGE OF THE WoOD STRUCTURE BUILDING IN THE COLD AREA}

\section{A. Adaptability of Climate}

Wood construction can adjust itself physical properties to adapt to the ambient conditions, such as timber capable of storing a certain amount of carbon dioxide and has a low coefficient of thermal characteristics. This property is particularly prominent in the building materials, reflected in the impact on the micro environment of building. With the development of society, people quickly realized that the climate adaptation characteristics of wood, for example in the Middle East railway period, the Russians built the traditional residential buildings (See Fig.1). Wooden structures were built from wood, thick wooden wall without any other material, it is just as insulated wall construction, which is to be proud of in the thermal conductivity of wood is very small, wooden structures have their own respiration, in summer it can play a very good ventilation effect, in winter it can effectively maintain indoor temperature, reducing heat loss [3]. 


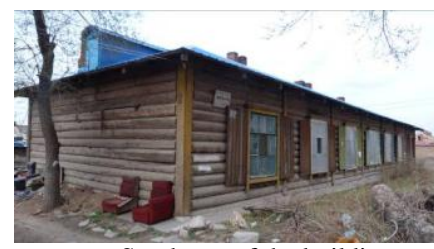

a. Southeast of the building

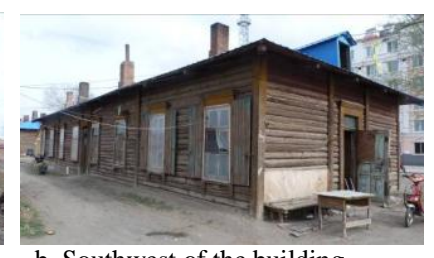

b. Southwest of the building
Figure 1. Wooden residential buildings in Manzhouli

\section{B. The Characteristics of Energy Saving}

1) Energy saving characteristics of wood structure building:

Wooden architecture is based on wood and wood elements. Wood is a natural, sustainable green building materials. It is a renewable resource and has unique energy efficiency. Wood has very good thermal insulation properties, for example, the use of advanced monolithic exterior wall structure in the wall of light wood frame construction, and efficient insulation material filled in the roof truss system, which can minimize heat loss. In modern technology, the heat transfer coefficient of the exterior wall of the wood structure building can reach about $0.5 \mathrm{~W} /(\mathrm{m} 2 \cdot \mathrm{K})$, the heat transfer coefficient of the roof reaches about $0.2 \mathrm{~W} /(\mathrm{m} 2 \cdot \mathrm{K})$ [4]. According to the results of the study of building environment and equipment engineering department in Tsinghua University, the results are reported as: Wooden structures than concrete structures EEB 8.1\%, than light steel structure EEB 5.3\%. (See Table I )

TABLE I. COMPARISON OF HEAT TRANSFER COEFFICIENT BETWEEN NEW WOOD STRUCTURE BUILDING AND REFERENCE BUILDING

\begin{tabular}{|c|c|c|}
\hline & $\begin{array}{c}\text { New wood } \\
\text { structure building }\end{array}$ & $\begin{array}{c}\text { Reference } \\
\text { building }\end{array}$ \\
\hline Body coefficient $\mathrm{S}$ & 0.34 & 0.34 \\
\hline $\begin{array}{l}\text { Roof heat transfer } \\
\text { coefficient } \mathrm{K}[\mathrm{W} /(\mathrm{m} 2 \cdot \mathrm{K})]\end{array}$ & 0.20 & 0.80 \\
\hline $\begin{array}{l}\text { Heat transfer coefficient of } \\
\text { exterior wall (including } \\
\text { non transparent curtain } \\
\text { wall) } \mathrm{K}[\mathrm{W} /(\mathrm{m} 2 \cdot \mathrm{K})]\end{array}$ & 0.50 & 1.00 \\
\hline
\end{tabular}

2) Production energy consumption of wood structure building materials:

The energy saving characteristic of the wood structure building is also reflected in the energy consumption of the building component. Factory of construction materials processing and on-site construction process, as well as waste disposal of garbage are energy consumption, its energy consumption is lower than $75 \%$ compared to the artificial industrial production process of reinforced concrete and steel and other building materials. With modern technology, the wooden structure components were prefabricated by industrial machinery production, then a standard component, these components are transported to the construction site for assembly, processing does not require heavy machinery. The construction method is very simple and low energy consumption, short construction period. This advantage is especially suitable for cold areas due to the long winter caused by the time delay problem. The biggest advantage of wooden structures is that more than $90 \%$ of the wood construction materials can be recycled, and the remaining waste can also be processed into other materials. (See Table II )

TABLE II. THERMAL PERFORMANCE DATA COMPARISON OF COMMON BUILDING MATERIALS

\begin{tabular}{|c|c|c|c|}
\hline & $\begin{array}{c}\text { Reinforced } \\
\text { concrete }\end{array}$ & $\begin{array}{c}\text { Steel } \\
\text { products }\end{array}$ & wood \\
\hline $\begin{array}{c}\text { Thermal } \\
\text { conductivity } \\
{[\mathrm{W} /(\mathrm{m} \cdot \mathrm{K})]}\end{array}$ & 1.74 & $13.7-43.6$ & $0.1-0.35$ \\
\hline $\begin{array}{c}\text { Heat storage } \\
\text { coefficient } \\
{[\mathrm{W} /(\mathrm{m} \cdot \mathrm{K})]}\end{array}$ & 17.2 & 126 & $3.885-6.93$ \\
\hline
\end{tabular}

\section{Short Construction Period}

The construction of the wooden structure is not affected by the climate in cold regions, and it can be construction in the four seasons. All the components of the wood structure building are pre standardized production in the factory [5], from the early design of the building, the factory prefabricated, component transport, and then to the field assembly, and after the completion of the test and subsequent maintenance and a series of complete industrial process, the construction is simple and quick (See Fig.2). A set of about $300 \mathrm{~m}^{2}$ wooden structure, in the mechanical conditions, it can be completed "rough housing" in 15 days, about three months, internal and external decoration can be completed.

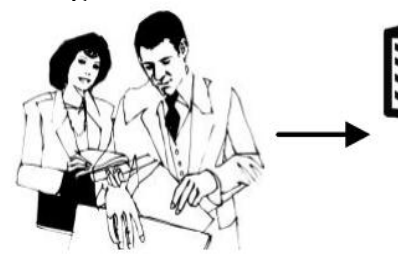

Pre-design

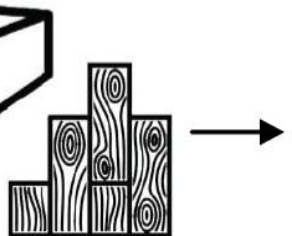

Factory precast

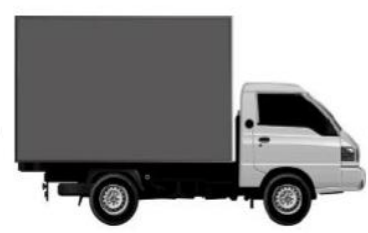

Component transportation

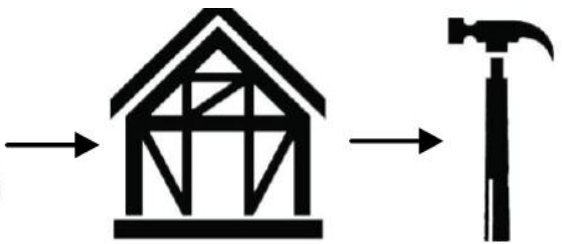

Field assembly Postmaintenance

Figure 2. Wooden residential buildings in Manzhouli 


\section{To SOLVE THE Problem OF MODERN WOOD STRUCTURE BUILDING}

There are many problems in the development of the wood structure building in the process of urbanization in our country. The existing design lack of evidence, for many of the wooden structure was not related to construction planning, Due to the climate and technical conditions, in the form of construction and application are very simple types, so it could not form a set of suitable for the current development of China's wood structure building technology system, in the aspect of building envelope are overall foreign material, so it can be not effectively reduce the construction costs [6]. In addition, the relevant technical standards are not perfect. There is no complete set of wood structure material certification system.

\section{A. Lag of Construction Technology of Wooden Structure Building}

Due to the lack of design basis, the existing wood structure has the problem that local structure is not reasonable, there is no mature structure system, which leads to the waste of timber. The wood structure building is also affected by the regional and other factors, in the cold climate, there are some structural members in the structure of the node has a split phenomenon in the buildings that have been built. In addition, the existing timber structure design code has not been improved yet. It is still in a state of revision. To promote the wooden structure in the process of urbanization, its technology needs further study and improve, learning foreign advanced technology, and then re-examine our existing wooden structure building.

At present, the existing wood structure building forms in China are mostly light wood structure, and the design code of wood structure provides that the number of layers of the structure should not be more than three layers [7]. However, in Europe and North American countries, they can be able to building more than three floors of wooden buildings a long time ago, and also to the development of high-rise buildings. Now, Canada, North America, Australia and other places built wooden buildings have reached a new height. At present, the world's tallest wooden frame building is located in Melbourne, Australia. It is the 10 storey building, 32 meters high. North America, now the highest wooden structure is designed by the architect Michael Green in October 2015 in the Prince George design and built Innovation and Design Centre Wood. It is the 7 storey building, which has a height of 29.5 meters. The main structure of the building with glued wood. Architect Michael Green has also designed the "giant plywood" (FFTT). This kind of wood board can be used in any combination like Lego, which can save half the time when it is built with the traditional materials. In addition, through the use of advanced CLT (Cross Laminated Timber) materials, in theory, the wooden structure can reach 33 layers. Canada began construction of the whole wood structure of the 18level student dormitory which is the world's tallest whole wood building in British Columbia University. (See Fig.3)

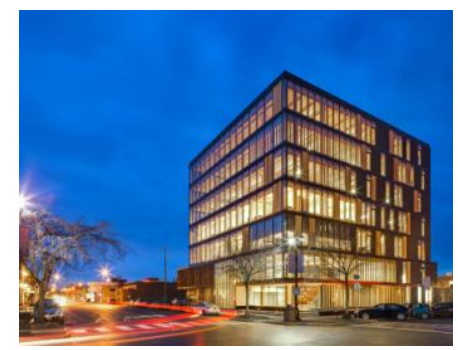

a. Design center perspective

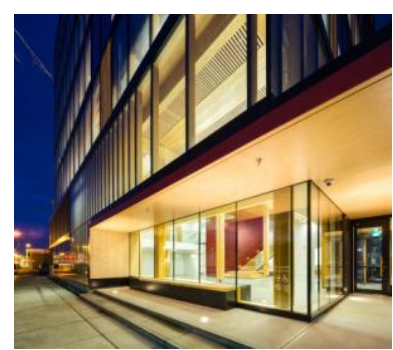

b. Design center entrance
Figure 3. Wood innovation and design center

In the condition of the contemporary technology, these foreign advanced wood structure technology can also be applied to the development of the domestic wood structure, we cannot just limited to the construction of wooden houses, but also even for multi-rise building, which will help reduce energy consumption, save construction costs, and in favor of wooden architecture in the process of urbanization and sustainable development.

\section{B. The Single Form of Wooden Structure}

In the process of urbanization, the construction of the cold area has changed the original building space model. The original architectural form of the city has changed accordingly. The development of urban architecture is full of metal atmosphere, thick reinforced concrete let the city's overall architectural space form into a box model, the multistorey and high-rise building construction form only through the combination of block and pile into the lack of regional characteristics. Because the wood structure is regarded as not durable and very expensive structural materials, most of wooden structure used to build in traditional houses in cold regions [8]. Now more structural forms are used for light wood structures (See Fig.4), the whole building is a combination of regular shape, they have double top and vertical wall surface, the external facade adopts foreign advanced thermal insulation external wall structure. It is difficult to have a big breakthrough in the architectural structure and architectural aesthetics.

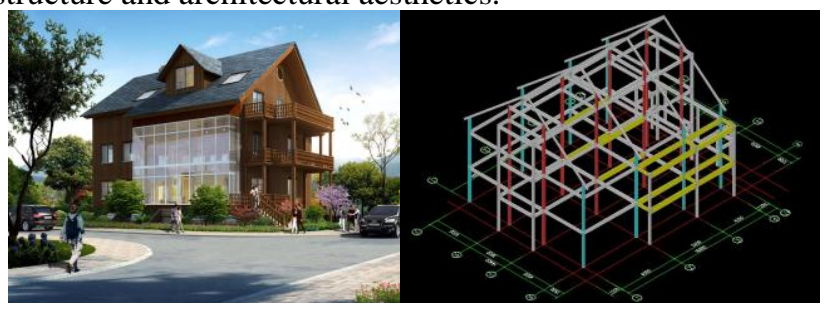

Figure 4. Wood structure building renderings and frame system of beam column

Under the modern technology, the wood structure building is the integration of the industrial production of wood, it breaks through the limit of the length of the natural wood, and increases the size of the section, in the form of the wooden building, and it has surpassed the traditional idea of the wood structure building [9]. In Japan, South Korea, and other countries in the Nordic countries, they have mastered the advanced technology of mature wood structure, according to the architect's design concept; it can be 
arbitrarily cut and composition processing the wood components. Figure 5 is the T type of housing in South Korea, this building uses $30 \mathrm{~cm}$ thick plywood to achieve the overall light wood structure, both ends of the $\mathrm{T}$ word is provoked to form home and contact porch living room and garden leisure platform, Suspension T type design is a good display of modern technology under the structural diversity of the wood structure housing, but also with the architectural style of modern art.

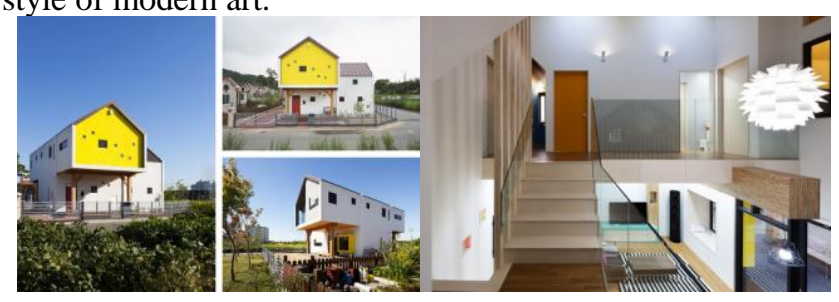

Figure 5. South Korea Iksan-si residential

Our country in the cold area people on the wood structure of cognitive development, still remain in the wooden expression. The performance of wood materials in the building decoration has been deeply rooted in the hearts of the people. People pay more attention to the design of wood engraving. Through the research on the architecture of foreign countries, we can use the existing resources and technology to design a reasonable design of wood structure.

\section{Some Common Mistakes}

In the process of urbanization in China, the application types of the wood structure building are not only restricted by the technical conditions, but also the lack of the standard of the national standard, In real life, people are exposed to the wooden structure is relatively simple, only wooden houses, villas, scenic construction, landscape architecture and streets in temporary wooden houses and other buildings, the size of the building is relatively small [10]. In the process of urbanization, the development of the wood structure building also promotes the development of the tourism economy. A lot of scenic spots and the recreation area of the city have been built the building which provides places for people to entertain. These buildings take advantage of the wooden structure, installation and removal does not require lifting equipment to ensure that the original appearance of the local environment. (See Fig.6) China's Arctic village tourism center is the most northern villages, it has beautiful environment and wealth of timber resources, winter cold, and there are not many villagers. Now, the village to develop the tourism industry, the style of the building retains the original style, which is used to build a wooden structure of the housing.

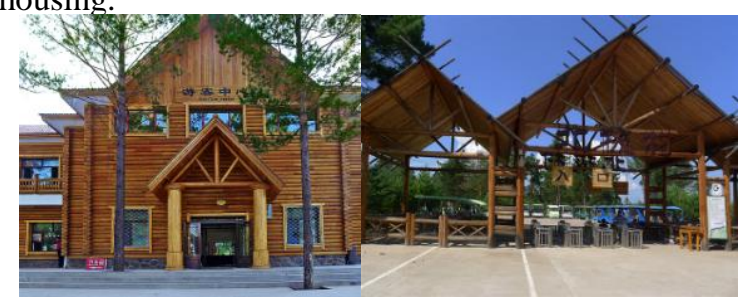

Figure 6. The wooden structure of Arctic Village Tourism
Another advantage is that this system can be widely used in small and medium structures, especially in light wood frame construction technology. Now, the technology has been very perfect, it has the advantages of strong stability, convenient construction, good seismic performance and low cost. At present, the individual southern city of China has established a model of energy saving wood building residential areas, such as Wujin green building industry cluster demonstration area. It has played an exemplary role in promoting the construction of wood structure.

\section{V.SUGGESTIONS ON ACCELERATING THE DEVELOPMENT OF WOOD STRUCTURE BUILDING IN COLD REGIONS OF CHINA}

Wood structure building has the advantages of stable structure, energy saving and environmental protection as well as cost economy prevails in future urbanization. Restricted in high cost, low income, domestic technology, and equipment, the development of wood construction in cold regions is relatively backward. Therefore, people are more likely to pursue short-term interests rather than longterm interests, such as paying for the application and innovation of technology. That leads the wooden structure of the building construction technology to be still in a few decades ago. As we all known, it is not available to promote the popularization and development of wood construction. With understanding the concept of green building deeply, the wooden structure will have great potential application in the cold area. To solve these problems, this work provides many suggestions for the development of the wood structure in the cold area of our country.

\section{A. Promoting Wood Structure Building}

Although people have realized gradually the advantages of wood structure building, its efforts in promotion and publicity are still far from enough. It is well known that wood structure building is not popular in our country, which results in being difficult to promote the construction of wood structure in the cold area. For that matter, the relevant departments of the local government should pay more attention for publicity by means of the media to convey the value of wood structure building and to promote consumption. In addition, relevant policies to promote the development of wood structure building, for example, giving developers a certain discount in order to encourage the construction of wood structure, should be completed.

\section{B. Expanding the Application of Wood Structure Building}

According to intrinsic characteristics, wooden structure of the building should possess a very large market share so we should expand its scope of application. First, under the conditions of limited land resources and meeting the interests of the developers, we should vigorously promote the development of new urban construction in the hybrid construction. This kind of construction has been applied in the construction of green low carbon demonstration area of separate cities in South China, which promotes the development of wood structure building. 
In the construction of some temporary exhibition venues, we should give priority to the use of the wooden structure because it can make fully use of the features of the wooden structure, such as easy disassembly and assembly, reusability and energy saving. What's more, it is very healthy to use wood structure in low buildings, for instance, kindergarten buildings and factories.

In addition, the level of wooden structure is relatively weak in China so we should both learn advanced timber technology by introduction from Europe and other countries and increase the ability of recycling and reuse of waste wood in order to enhance China's wood construction quality and improve the utilization rate of wood. At present, China is carrying out actively wood recycling activities by mixing recycled waste wood with other materials to produce new building materials. For the old wooden structure building, for example, residential buildings along the Middle East Railway, we could apply the new processing techniques keeping used traces to arouse people's cultural awareness. Therefore, it can promote wooden structure development in city construction faster and better.

\section{REFERENCES}

[1] Wang Peibin. Research on NC abrasive belt-grinding trajectory of the turbine blade [J] Journal of Shenyang Institute of Engineering (Natural Science), 2014 (01): 86-91.
[2] Yuan Dong, Wand Xiaohuan, Fei Benhua, Du Mim. Status and Advantage Analysis of Developing Modern Wood Construction in China [J] Forestry Economics, 2011 (10): 61-63.

[3] Wang Xiaohuan, Fei Benhua, Zhao Rongjun, Zhou Haibin. Development and Research Status of Energy-efficiency of Wood Construction [J] Building energy conservation, 2008 (03): 24-26.

[4] Zhang Jiuhong, Xie Huanhuan. Energy-Saving Building from Nordic-Finnish Enemy Saving and Environment-Friendly Model Wooden Villa [J] Journal of Shenyang Jianzhu University (Social Science), 2012 (01): 6-8

[5] Lou Wanli, Ren Haiqing. Characteristics and Prospects of Wood Structure Buildings in China [J] Wood Industry, 2015 (09): 21-23.

[6] Han Xiaofeng, Hao Junhong. A Study on the Structural Typology of Contemporary Wooden Architecture [J] New Architecture, 2015 (02) :116-117.

[7] Wang Chengyan, Wang Xiao. Reflection of the Development of Timberwork Building in China [J] Forest Products Industry, 2013 (07): 14-16.

[8] Chen Rong. Research on the Composition and Expression of Modern Timber Architectural Form [D] Nanjing Tech University, 2014 (05): 9-11.

[9] Hou Jianfen, Wang Jing. The Development of Modern Timber Building Technology and Its Application Feature in Space $[\mathrm{J}]$ New Technology, 2006 (06): 111-113.

[10] Yu Ning. The Research on Contemporary Timber Building's Architectural Expressions and Application [D] Dalian University of Technology,2010(06):23-27. 